\title{
Benefits of Stryphnodendron adstringens when associated with hydrogel on wound healing in diabetic rats
}

Patricia de Souza de Aguiar ${ }^{1}$, Áurea Pandolfo Correa², Flavia Tasmin Techera Antunes', Alexandre Falcão de Barros Ferraz', Suele Biehals Vencato², Gabriela Jouglard Vasques Amado ${ }^{1}$, Elenir Wiiland ${ }^{2}$, Dione Silva Corrêa', Ivana Grivicich ${ }^{1}$ and Alessandra Hubner de Souza ${ }^{1 *}$ (i)

\begin{abstract}
The plant Stryphnodendron adstringens is a species of legume in the genus Stryphnodendron that is found in Brazil. It is also known as "barbatimão-verdadeiro" and it is popularly used in folk medicine due to its healing properties. Purpose: The aim of this study was to evaluate the healing activity of hydrogel, together with an S. adstringens hydroalcoholic extract, in diabetic and non-diabetic rats. Methods: The phytochemical analysis of the $S$. adstringens hydroalcoholic extract was evaluated through HPLC and its antioxidant activity was measured by the DPPH assay. The cytotoxicity, the scratch assay, and the fibroblast cell proliferation were also evaluated. Forty (40) Wistar rats were submitted to an excision for a full-thickness wound of $1.5 \mathrm{~cm} \times 1.5 \mathrm{~cm}$ in their dorsum. The animals were treated twice a day over 16 days, with a rich layer of the corresponding treatment: Hydrogel; Hydrogel associated with 5\% S. adstringens hydroalcoholic extract (H+SAHE); S. adstringens hydroalcoholic extract (SAHE); Collagenase with Chloramphenicol; or Carbopol. Morphological and histological analyses of the injury were performed. Results: The phytochemical analysis of SAHE indicated the presence of phenolic compounds, tannins, and flavonoids. The hydroalcoholic extract showed strong antioxidant activities $\left(I C_{50}=25.56 \pm 1.04 \mu \mathrm{g} / \mathrm{mL}\right)$. H + SAHE induced the fibroblast proliferation $(148 \pm 6.9 \%)$ and it was not cytotoxic. The association with $\mathrm{H}+\mathrm{SAHE}$ showed a more pronounced healing activity than did the other treatments in the non-diabetic animals and in the diabetic animals, hence, promoting angiogenesis and reepithelialization. Conclusion: Under these scenarios, this study has demonstrated effectiveness in the recovering wounds of diabetic rats.
\end{abstract}

Keywords: Healing properties, Wound care, Stryphnodendron adstringens, Hydrogel, Diabetic animals

\section{Highlights}

- H+SAHE promoted angiogenesis and Reepithelialization.

- $\mathrm{H}+\mathrm{SAHE}$ induced the fibroblast proliferation and it was not cytotoxic.

\footnotetext{
* Correspondence: alessandrahubnersouza@gmail.com

'Postgraduate Program in Cellular and Molecular Biology Applied to Health, Lutheran University of Brazil, Av. Farroupilha, 8001, District São José, Canoas, Rio Grande do Sul 92425900, Brazil

Full list of author information is available at the end of the article
}

- H+SAHE showed effectiveness in the recovering wounds of diabetic rats

\begin{abstract}
Introduction
Several processes are involved in wound healing, such as inflammation, cell proliferation, and a contraction of the collagen that is formed $[1,2]$. Wound healing in Diabetes Mellitus (DM) patients is characterized by an inhibition of the inflammatory response, angiogenesis, and fibroplasia, as well as defects in the collagen deposition and in the differentiation of the extracellular matrix [3, 4]. It is known that the most important repair failures
\end{abstract}

\section{Springer Open}

(c) The Author(s). 2021 Open Access This article is licensed under a Creative Commons Attribution 4.0 International License, which permits use, sharing, adaptation, distribution and reproduction in any medium or format, as long as you give appropriate credit to the original author(s) and the source, provide a link to the Creative Commons licence, and indicate if changes were made. The images or other third party material in this article are included in the article's Creative Commons licence, unless indicated otherwise in a credit line to the material. If material is not included in the article's Creative Commons licence and your intended use is not permitted by statutory regulation or exceeds the permitted use, you will need to obtain permission directly from the copyright holder. To view a copy of this licence, visit http://creativecommons.org/licenses/by/4.0/. 
are those that occur in the initial stages of the lesion, leading to edema, a reduction of vascular proliferation, and a decrease in the number of leukocytes, macrophages, and fibroblasts [5].

In addition to the sequence of reactions that are involved in the cicatricial process, healing in humid environments has advantages when compared to the dry environment. This would include the prevention of tissue dehydration that can lead to cell death; an acceleration of angiogenesis; a stimulation of epithelization and the formation of granulation tissue; facilitation of the removal of necrotic tissue and fibrin, being a protective barrier function against microorganisms; the promotion of pain reduction; and an avoidance of the excessive loss of fluids and traumas in the dressing exchange [6]. One of the substances that have been highlighted for wound healing is hydrogel. Recent studies have shown that the use of hydrogels as biomaterials in wound healing is promising. When mixed with bioactive substances, they have a high power to recover the lesion. Hydrogel not only absorbs the exudate, but it also prevents the loss of water by evaporation and dehydration of the lesion, stimulating the healing process $[7,8]$.

Stryphnodendron adstringens, also known as barbatimão-verdadeiro, is commonly used as an antibacterial, an anti-inflammatory, an antiseptic, an astringent, as well as for wound healing. It has several active compounds that are produced by its secondary metabolism, such as alkaloids, terpenes, flavonoids, steroids, and tannins $[9,10]$. S. adstringens has proven therapeutic efficacy and its extracts may present beneficial effects in the stimulation of the healing process [11]. Recently, the use of $S$. adstringens has been widely reported in phytotherapeutic production for this healing purpose, in the form of ointments and cream [12].

Thus, the present study has aimed at performing a screening in the hydroalcoholic extracts of $S$. adstringens, in order to link the effects of $S$. adstringens in vivo when associated with hydrogel, on the healing process of skin lesions in diabetic rats. The antioxidant activity, the cytotoxicity, and the proliferative effects in vitro of this gel were also evaluated.

\section{Materials and methods}

\section{Plant material and extract preparation}

The extract of $S$. adstringens was prepared according to the Brazilian Pharmacopoeia, 4th Edition. Briefly, $200 \mathrm{~g}$ of $S$. adstringens bark that was purchased from Florien e Cia Ltda, Brazil, was macerated for 7 days in $800 \mathrm{~mL}$ alcohol $70^{\circ} \mathrm{GL}$. After that, this extract was filtered and concentrated to dryness, under reduced pressure and a temperature lower than $40{ }^{\circ} \mathrm{C}$, yielding $45.8 \mathrm{~g}(18.3 \%$, w/ $w)$. The extract was kept in vacuum desiccators to produce a completely dry solid mass.

\section{Phytochemical analysis}

The $S$. adstringens extract was subjected to qualitative chemical screening for the identification of the major classes of the active constituents. The phytochemical profile of the $S$. adstringens extract was determined through the method that consists of colorimetric reactions for the qualitative detection of flavonoids, tannins, anthraquinones, alkaloids, saponins, and coumarins [13, 14]. The thin-layer chromatography analysis was performed as described by Wagner and Bladt [15].

\section{Total contents of Phenolics in the S. adstringens extract}

The total contents of the phenolic compounds in the $S$. adstringens extract were determined by the FolinCiocalteu method. The ethanolic solutions of gallic acid were mixed with $5 \mathrm{~mL}$ of Folin-Ciocalteu reagent and 4 $\mathrm{mL}(75 \mathrm{~g} / \mathrm{L})$ of sodium carbonate. After $30 \mathrm{~min}$, the absorption was read at $765 \mathrm{~nm}$ and the calibration curve was drawn [15]. Following this, $1.0 \mathrm{~mL}$ of the extract was mixed with the same reagents as described above, and after $1 \mathrm{~h}$, the absorption was measured to determine the total phenol solution $(0.1 \mathrm{mg} / \mathrm{mL})$. The total phenol contents were expressed as gallic acid (Sigma, St. Louis, $\mathrm{MO}$, USA) equivalents (GAE) in $\mathrm{mg} / \mathrm{g}$ of extract [16]. All of the determinations were performed in triplicate.

\section{Total contents of tannins in the S. adstringens extract}

The total contents of tannins were determined by using the casein precipitation assay. The tannins were also analyzed according to the Folin-Ciocalteu method and the solution was shaken for $1 \mathrm{~h}$. After that, the solution was filtered, and $1 \mathrm{~mL}$ of this solution was mixed with $5 \mathrm{~mL}$ Folin-Ciocalteu reagent and $4 \mathrm{~mL}$ sodium carbonate; the absorptions were measured after $1 \mathrm{~h}$. The entire assay was performed in triplicate and the total contents of the tannins were expressed as gallic acid (Sigma, St. Louis, $\mathrm{MO}$, USA) equivalents (GAE) in $\mathrm{mg} / \mathrm{g}$ of extract.

\section{Determination of the Total flavonoid contents in the S. adstringens extract}

The total flavonoid contents of the $S$. adstringens extract were determined by a previously described colorimetric method when using aluminum chloride [17]. The solutions were prepared with varying concentrations of quercetin (Sigma, St. Louis, MO, USA), in order to establish the calibration curve $(2-12 \mu \mathrm{g} / \mathrm{mL})$.

After $30 \mathrm{~min}$, the absorption was measured at $425 \mathrm{~nm}$ for each solution by a Shimadzu spectrophotometer (UV-1602PC, Kyoto, Japan). The analyses were carried out in triplicate and the total samples were expressed as quercetin equivalents $(\mathrm{QE}) \mathrm{in} \mathrm{mg} / \mathrm{g}$ of extract. 
HPLC analysis of the phenolic composition from the $S$. adstringens extract

The chromatographic analyses were carried out by a validated method by using the Reversed-phase HPLC (Waters 2695 Alliance Separation Module) technique. This was equipped with a Waters 2487 I Dual Wavelength UV Detector and controlled by an IEEE-488 interface module. As a stationary phase, a Waters Spherisorb ODS2 ReversedPhase Column $(250 \times 4.6 \mu \mathrm{m}-5 \mathrm{~mm}$ diameter particles $)$ was used. A constant flow-rate of $1 \mathrm{~mL} \cdot \mathrm{min}^{-1}$ was used during the analyses. HPLC grade solvents and Milli-Q ${ }^{\circ}$ water were used in the chromatographic studies. The phenolic acids and the flavonoids were quantitatively determined at $254 \mathrm{~nm}$ when using pure acetonitrile (A) and $0.1 \%$ phosphoric acid $\left(\mathrm{H}_{3} \mathrm{PO}_{4}\right)(\mathrm{B})$ as the mobile phases. The gradient system was adjusted to $0 / 95,20 / 86$, and $70 /$ 65 ( $\mathrm{min} / \% \mathrm{~B})$. Phenolic standards were used as an external standard. The analytical curves were constructed for all of the phenolic standards that were used, by plotting the peak area of the compound versus the concentration, while using five standard solution spots in the concentrations range. The analytical generated curve was obtained by linear regression (peak area versus the standard concentration). The correlation of the chromatographic peaks was achieved by comparing the experimental retention times to those used as an external standard. Their amounts were quantified $(\mathrm{mg} / \mathrm{mL})$ by a standard curve. The accuracy of the results was evaluated by the performance parameters (limit of detection (LOD), limit of quantification (LOQ), linear equation, and linear regression). All of the chromatographic operations were carried out in triplicate at room temperature.

\section{Gel preparation}

Three gels were prepared, using respectively, saline $0.9 \%$ (Hydrogel), saline $0.9 \%$ associated with $5 \%$ S. adstringens extract $(\mathrm{H}+\mathrm{SAHE})$, and Carbopol (negative control). The carbomer, 1\% Carbopol 940, was utilized, in order to provide viscosity to the gels and its $\mathrm{pH}$ was adjusted to 7.0 with AMP 95 (Aminomethyl Propanol, Mapric Produtos Farmacocosméticos Ltda, São Paulo, Brazil).

\section{Antioxidant activity by the DPPH assay}

The ability of SAHE to extinguish the stable radical, di (phenyl) - (2,4,6-trinitrophenyl) iminoazanium (DPPH) (Sigma, St. Louis, MO, USA), was measured according to the method as described by Mensor et al., [18]. Methanol was used as a blank, DPPH/methanol was used as a negative control, and gallic acid was used as a positive control sample. After $30 \mathrm{~min}$, the absorbance was measured at $518 \mathrm{~nm}$ when using a Shimadzu spectrophotometer (UV-1602PC, Kyoto, Japan). The measurements were performed in triplicate, and the antioxidant activity was calculated according to the formula:

\%inhibition of DPPH $=[($ Abscontrol( $(+)$-Abssample $) \times 100] /$ Abscontrol(+).

\section{Cell culture conditions and treatment}

The Mus musculus fibroblasts L929 cell line (RJCB Collection, Rio de Janeiro, Brazil), was routinely maintained in medium DMEM (Invitrogen Corporation, Carlsbad, CA, USA) suplemented with $10 \%$ fetal bovine serum (v/ v; Cultilab, Campinas, SP, Brazil) at $37{ }^{\circ} \mathrm{C}$ and with $5 \%$ $\mathrm{CO}_{2}$, and humidity of at least $95 \%$.

A pilot study was conducted, in order to define the concentration to be tested in the in vitro assays. Concentrations of $0.5,1.0,4.0$, and $8.0 \mathrm{mg} / \mathrm{mL}$ were tested. The $4.0 \mathrm{mg} / \mathrm{mL}$ concentration was the one chosen since it was the maximum dose that was capable of being dissolved in the culture medium.

\section{Cytotoxicity and proliferation assays}

The cytotoxicity was evaluated by using the colorimetric assay of MTT (3- (4,5-dimethyl-2-thiazolyl) -2,5-diphenyl$2 \mathrm{H}$-tetrazolium bromide, Life Technologies ${ }^{\mathrm{Tm}}$, Oregon, USA). The quadruplicate cultures were exposed to the gels for $24 \mathrm{~h}$. After the treatments, the cells were incubated with $100 \mu \mathrm{L}$ of MTT solution $(0.1 \mathrm{mg} / \mathrm{mL}$ MTT) in the culture medium, without FCS, and without phenol. They were cultured at $37^{\circ} \mathrm{C}$ for $4 \mathrm{~h}$. After the incubation, the supernatant was carefully removed, and the purple formazan crystals were solubilized in $200 \mu \mathrm{L}$ of DMSO (10\%) [19]. The assay was performed by a microplate reader (Multiskan, Uniscience, Sao Paulo, SP, Brazil), with an optical density of $540 \mathrm{~nm}$. The cytotoxic effects were determined based upon ISO10993-52009. A reduction of cell viability by over $30 \%$ was considered cytotoxic.

For the cell proliferation study, the L929 cells were seeded in 24-well flat-bottom plates at a density of $2 \times$ $10^{4}$ cells/well and they were stabilized for $24 \mathrm{~h}$. Afterward, the cells were exposed to the gels for another $24 \mathrm{~h}$. The evaluation of the proliferative effects was performed as described by Sigalas et al. [20]. The cells were counted in four random fields by using a Neubauer chamber. Finally, the average number of cells per plate-well was calculated.

\section{Scratch wound assay}

The L929 cell line were seeded in quadruplicate in 24well plates at a density of 105 cells/well. The plates were maintained at $37{ }^{\circ} \mathrm{C}$ and with $5 \% \mathrm{CO} 2$ in a moist atmosphere overnight, in order to obtain a confluent cell monolayer. The confluent monolayers were scratched with a pipette tip and the culture medium was immediately removed and was replaced by a non-supplemented 
fresh medium [21]. The cell migration was analyzed by photographs after $0 \mathrm{~h}$ and $24 \mathrm{~h}$, following the creation of the lesions. The images were analyzed by using ImageJ software (version 1:48), and the results of the migration were expressed in the form of a percentage. Time 0 was considered as being equivalent to $100 \%$ of the width of the risk measure. The results were expressed in percentages of the wound closure.

\section{Animals}

Forty (40) male Wistar rats, with ages ranging between 60 and 80 days, at $200-250 \mathrm{~g}$ weight, were obtained from the Lutheran University of Brazil (ULBRA) vivarium. They were individually maintained in standard cages, with a 12-h light/dark cycle, and in a temperature-controlled room $\left(23 \pm 2{ }^{\circ} \mathrm{C}\right)$. Food and water were allowed ad libitum. All of the in vivo experiments were approved by the Ethics and Animal Experimentation Committee of the Center for the Lutheran University of Brazil (ULBRA) (CEUA), Protocol N ${ }^{\circ}$ 2014-2P. This study followed the guidelines for animal research, in accordance with the Guide for Laboratory Animal Care in Research Experiments of the National Council for Animal Experimentation Control (CONCEA), in accordance with the ARRIVE Guidelines [22] and conducted in accordance with the internationally accepted principles for laboratory animal use and care as found in for example the European Community guidelines (EEC Directive of 1986; 86/609/EEC).

\section{Diabetes mellitus model}

The DM model was induced by a single intraperitoneal injection of $80 \mathrm{mg} / \mathrm{kg}$ of the diabetogenic drug streptozotocin (Sigma Chemical Company, St. Louis, MO, USA), which was dissolved in a $0.1 \mathrm{M}$ citrate buffer $(\mathrm{pH}$ 4.5) [23]. Hyperglycemia was confirmed when the glucose levels exceeded $200 \mathrm{mg} / \mathrm{dL}$. This was confirmed by an Accu-Check ${ }^{\circ}$ (Roche Diagnostics) on day 3 after the inductions.

\section{Wound creation and treatments}

For the surgical procedures, the rats were anesthetized with a mixture of ketamine $(100 \mathrm{mg} / \mathrm{kg})$ and xylazine $(10 \mathrm{mg} / \mathrm{kg})$ by an intraperitoneal route. The dorsum of the rats was previously shaved and was disinfected with $70 \%$ ethylic alcohol, in order to excise a full-thickness wound of $1.5 \times 1.5 \mathrm{~cm}^{2}$, using a pair of sharp scissors and a scalpel. The non-diabetic rats and the diabetic rats were randomly divided into five groups $(n=08)$. The animals received treatments according to the following groups: Hydrogel; $\mathrm{H}+\mathrm{SAHE}$; SAHE; Collagenase with Chloramphenicol; and Carbopol. Each wound was treated twice a day, with a rich layer $( \pm 2 \mathrm{~g})$ of the corresponding treatment, for 16 days.

\section{Morphological analysis of the injury}

The wounds were photographed on the 4th, 8th, 12th, and 16th day, by using a digital camera from a standard distance of $30 \mathrm{~cm}$. The images were analyzed with ImageJ Image-Processing Software (NIH, Bethesda, MD, USA), in order to estimate the area of the wounds. On the same days, the appearance and the exudate production of the wounds were also evaluated. For the morphological analyses, which were conducted at different times, the study used the method of evaluation of the healing process, PUSH (Pressure Ulcer Scale for Healing) [23], which considers the parameters of the presence of a crust, the reepithelialization, the granulation, and the slough. The appearance of the wound was defined as being necrotic tissue, slough, epithelial tissue, or as a closed wound. These designations were matched with scores of 0 (wound closed), 1 (epithelial tissue), 2 (granulation tissue), 3 (slough), and 4 (necrotic tissue). The amount of the exudate that was present in the wound was assessed before applying any topical agent and it was classified as absent (0), small (1), moderate (2), and large (3).

\section{Histological analysis}

One specimen from each group was collected on the 8th, 12th, and 16th day after surgery for the histological analyses (all of the remaining animals were sacrificed on the 16th day by an overdose inhalation of isoflurane). The specimens were fixed in $10 \%$ formalin for $24 \mathrm{~h}$. After conventional ethanol gradient dehydration, the tissues were embedded in paraffin and they were sectioned at $5 \mu \mathrm{m}$. For the histological analyses, the sections were stained with Hematoxylin and Eosin (H\&E) and Masson's Trichrome (MT). The histological examination of the tissues was performed by a pathologist who was blinded to the experiment. The histological changes were evaluated by considering the density of the inflammatory cells, the thickness of the granulation tissues, and the thickness of the epithelial layers. At least six areas of each slide were analyzed.

In the tissues that were stained with HE, the presence of a crust and a reepithelialization in the epidermis were evaluated, as well as the dermal hemorrhage and neovascularization. The data that was obtained for these parameters was graded according to the intensity by: absent - up to $15 \%$ (0), very little - $20 \%$ (1) low - $50 \%$ (2) moderate $-80 \%$ (3), and very high - up to $100 \%$ (4). At least two fields of each blade were analyzed. MT was used to assess collagen deposition. The collagen area percentages were evaluated by using ImageJ Software Version 1:48, with the Color Deconvolution Plugin.

\section{Statistical analysis}

The analysis results of the lesion contractions and the morphological analysis of the lesions were studied by 
Two-Way Analysis of Variance (ANOVA), followed by Bonferroni's test when using GraphPad 4 Software (USA). For the cell proliferation and the cell migration study, One-Way ANOVA, followed by the StudentNewman-Keuls (SNK) post hoc test, were used. All of the data was expressed as mean \pm standard error and it was considered a significant value if $p<0.05$.

\section{Results}

\section{Phytochemical screening and HPLC analysis of the $S$. adstringens extract}

The qualitative phytochemical screening of Stryphnodendron adstringens suggested the presence of tannins and flavonoids. The quantitative phytochemical analyses of the $S$. adstringens hydroalcoholic extract determinated the amounts of total phenolics $(320.20 \pm 6.37 \mathrm{mg} \mathrm{GAE} / \mathrm{g}$ of extract), tannins (158.13 $\pm 6.01 \mathrm{mg} \mathrm{GAE} / \mathrm{g}$ of extract), and flavonoids $(4.29 \pm 0.55 \mathrm{mg} \mathrm{QE} / \mathrm{g}$ of extract). The HPLC analysis (Table 1 and Fig. 1) showed the presence of gallic acid (peak 1) and caffeic acid (peak 2) in the $S$. adstringens hydroalcoholic extract. Rutin was also detected but the amount was lower than the limit of detection (LOD) and the limit of quantification (LOQ).

\section{Antioxidant activity}

The $S$. adstringens extract showed lower antioxidant activity by the $\mathrm{DPPH}$ assay $\left(\mathrm{IC}_{50}=25.56 \pm 1.04 \mu \mathrm{g} / \mathrm{mL}\right)$ when compared with the positive control $\left(\mathrm{IC}_{50}\right.$ gallic acid $=5.49 \pm 0.24 \mu \mathrm{g} / \mathrm{mL}$ ).

\section{Cytotoxicity and the proliferation assays}

Hydrogel and $\mathrm{H}+$ SAHE did not induce cytotoxicity when in comparison to the positive control (DMSO $10 \%)$. In order to confirm these effects, the researchers performed proliferation assay. Hydrogel induced fibroblast proliferation $(267 \pm 3.4 \%, p<0.05)$ in comparison to the negative control $(156 \pm 8.9 \%)$. All of the other treatments did not induce cell proliferation when compared to the untreated control (Carbopol: $150 \pm 5.2 \%$; SAHE: $122 \pm 7.4 \%$ and $H+$ SAHE: $148 \pm 6.9)$. In summary, the results indicated that Hydrogel was not cytotoxic and it stimulated cell proliferation.

\section{Scratch wound assay}

The evaluations showed that the closure started to improve at $24 \mathrm{~h}$ after the scratch was inflicted in the cells that were treated, and also in the untreated control cell. SAHE $(43 \pm 4 \%, p<0.05)$ and Hydrogel $(37 \pm 5 \%)$ reduced the area in a way similar to the negative control $(36 \pm 5 \%)$. The extent of the scratch closure was better for the $\mathrm{H}+$ SAHE group $(79 \pm 11 \%, p<0.01)$, followed by the Carbopol group $(55 \pm 4 \%, \mathrm{p}<0.01)$, which showed a higher effect on recovery from the scratch. Thus, this has suggested that $\mathrm{H}+$ SAHE, besides inducing cell proliferation, can stimulate cell migration, which is also an important process in the wound healing of the skin.

\section{Wound contraction evaluation}

In the non-diabetic animals, on the fourth day of treatment, the Hydrogel group presented a greater wound contraction $(32.97 \pm 3.68 \%)$ than did the SAHE group $(10.84 \pm 5.75 \%, p<0.001)$. However, the SAHE group showed a lower percentage of contraction than did the $\mathrm{H}+$ SAHE group (20.21 $\pm 5.83 \%)$ (Figs. 2a and 3a).

On the 8th day, the Hydrogel group (46.92 $\pm 4.85 \%)$, in comparison with the other groups, was able to better the wound in a shorter amount of time. On the 12th day, Hydrogel presented a lower contraction $(70.01 \pm 3.83 \%)$ when in comparison to the SAHE group $(84.45 \pm 5.90 \%$, $p<0.05)$. On the 16th day, no significant differences were observed. The Collagenase with Chloramphenicol ${ }^{\circ}$ group revealed a greater contraction of the wounds at the end of the treatments $(87.75 \pm 3.29)$, although there was a delay in the contraction of the wounds in the early days, with a bad appearance.

Marked bleeding and a detachment of the edge of the wound were noted in all of the groups, except in the Collagenase with Chloramphenicol $^{\circ}$ group. There was a crust formation on the 8th day. From day 12 onwards, there was a decrease in the depth of the wound, together with a contraction of the margins.

In the diabetic animals (Figs. $2 \mathrm{~b}$ and $3 \mathrm{~b}$ ), significant differences were observed only on day 8 in the Hydrogel treatment group, displaying superior contractions $(32.49 \pm 6.98 \%)$ when compared to the group that was treated with SAHE $(15.55 \pm 5.37 \%, p<0.05)$. There was the presence of a slight granulation on day 4 , except in

Table 1 Hydroethanolic extract of S. adstringens analyzed by HPLC. Retention time in minutes and the amounts of phenolic compounds in $\mu \mathrm{g} / \mathrm{mL}$

\begin{tabular}{|c|c|c|c|c|c|c|c|}
\hline Peak & Compound & Retention time (min) & Mean \pm SD & Linear equation & Linear rProgression & $\begin{array}{l}\operatorname{LOD} \\
\left(\mu \mathrm{g} \mathrm{L}^{-1}\right)\end{array}$ & $\begin{array}{l}\mathrm{LOQ} \\
\left(\mu g \mathrm{~L}^{-1}\right)\end{array}$ \\
\hline 1 & Gallic acid & 4.9 & $113.7 \pm 0.02$ & $y=7 E+06 x+10,931$ & 0.9961 & 0.0061 & 0.0202 \\
\hline 2 & Caffeic acid & 14.6 & $28.23 \pm 0.01$ & $y=23,610 x+46,127$ & 0.9985 & 0.2095 & 0.6983 \\
\hline 3 & Rutin & 32.8 & a & $y=20,710 x+50,367$ & 0.9999 & 0.0654 & 0.2179 \\
\hline
\end{tabular}

${ }^{\mathrm{a}}$ Presence detected but not quantified 


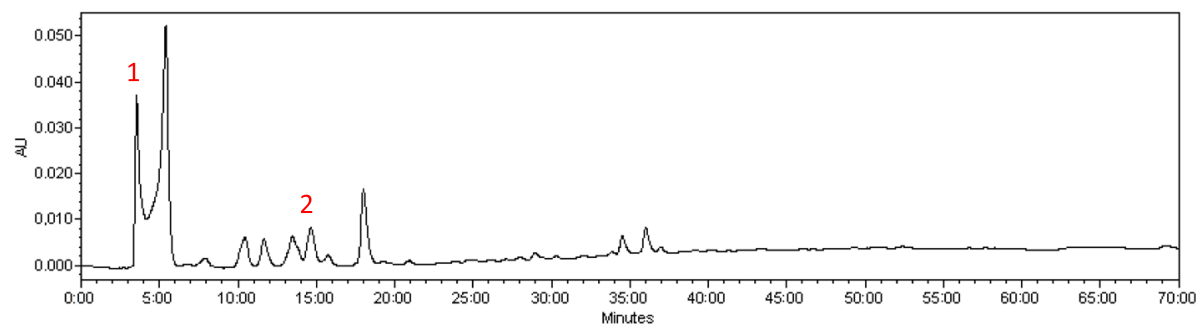

Fig. 1 Full chromatogram of SAHE

the diabetic animals that were treated with Carbopol, which showed signs of necrosis.

\section{Morphological analysis of the lesions}

It was possible to observe that both groups of Collagenase with Chloramphenicol $^{\circ} \quad(2.87 \pm 0.10 ; 2.0 \pm 0.15$; $1.51 \pm 0.15$ and $0.86 \pm 0.10)$ and Carbopol ( $2.37 \pm 0.25$; $2.25 \pm 0.29 ; 1.38 \pm 0.26$ and $1.36 \pm 0.29)$ kept high scores of exudate in all periods of the treatment in the control rats. In the control animals, on the fourth day of treatment, significant differences were found in the $\mathrm{H}+$ SAHE group $(1.12 \pm 0.27, p<0.001)$ when compared to the Hydrogel group $(2.2 \pm 0.13)$ and with the $\mathrm{H}+\mathrm{SAHE}$ group $(1.12 \pm 0.27, p<0.001)$. Differences were also identified with the SAHE group on days 8,12 , and $16(0.0 \pm$ $0.0, \mathrm{p}<0.001)$. The same notifications happened with the $\mathrm{H}+$ SAHE group $(0.23+0.1, \mathrm{p}<0.001)$ (Fig. 4a).
In the diabetic animals, it was observed that on the fourth day, the exudate production was lower in the Hydrogel-treated group $(1.2 \pm 0.2)$ when compared to the Carbopol $(2.4 \pm 0.24, p<0.01)$ and Collagenase with Chloramphenicol $^{\circ}(2.0 \pm 0.36, p<0.05)$ groups. On day 16 , it was evidenced that the Hydrogel group $(0.0 \pm 0.0$, $p<0.001)$ and the $\mathrm{H}+$ SAHE group $(0.0 \pm 0.0, \mathrm{p}<0.001)$ extinguished the exudate (Fig. 4b).

In the related wound appearances (Fig. 5a), it was observed that both sets of the control animals that were treated with Carbopol $(3.6 \pm 0.24 ; 4 \pm 0.0 ; 3.8 \pm 0.2 ; 3.2 \pm$ $0.2, \mathrm{p}<0.001)$ had the worst appearance on all of the days. The Collagenase with Chloramphenicol ${ }^{\circ}$ group $(3 \pm 0.00 ; 3.67 \pm 0.33 ; 2.67 \pm 0.42 ; 2.0 \pm 0.36)$ also had a bad appearance, and further, the SAHE group $(4 \pm 0.0$; $4 \pm 0.0 ; 4 \pm 0.0 ; 1.83 \pm 0.47)$ only improved on day 16 . During the treatments, the Hydrogel group $(3 \pm 0.0 ; 2 \pm$ $0.0 ; 1.57 \pm 0.2 ; 1.71 \pm 0.28)$ and the $\mathrm{H}+\mathrm{SAHE}$ group
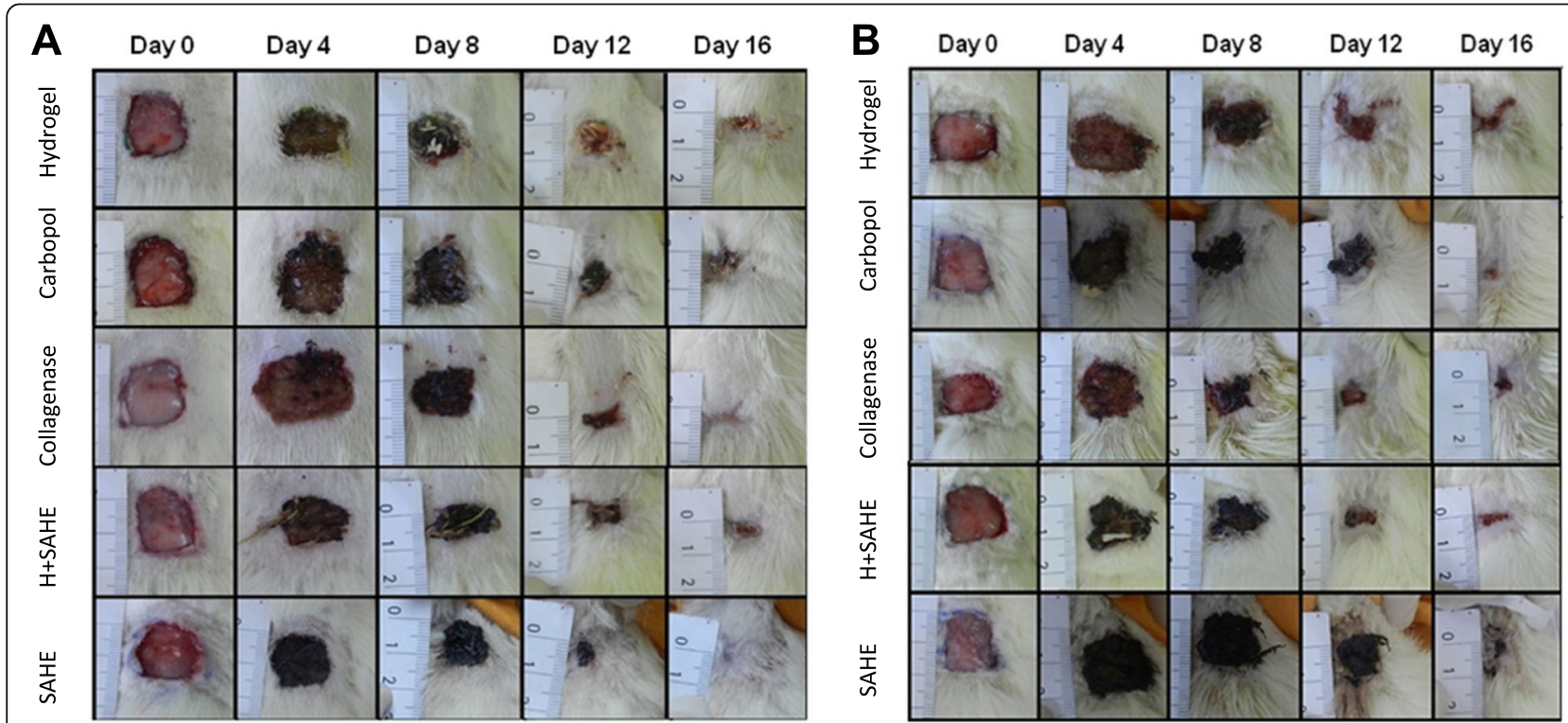

Fig. 2 Cutaneous wound contraction measurements in the rats on days 4, 8, 12, and 16. Image of the lesions in the non-diabetic animals (a) and in the diabetic animals (b), shown in days of the respective treatments: Hydrogel, Carbopol, Collagenase with Chloramphenicol ${ }^{\oplus}, \mathrm{H}+\mathrm{SAHE}$, and SAHE 

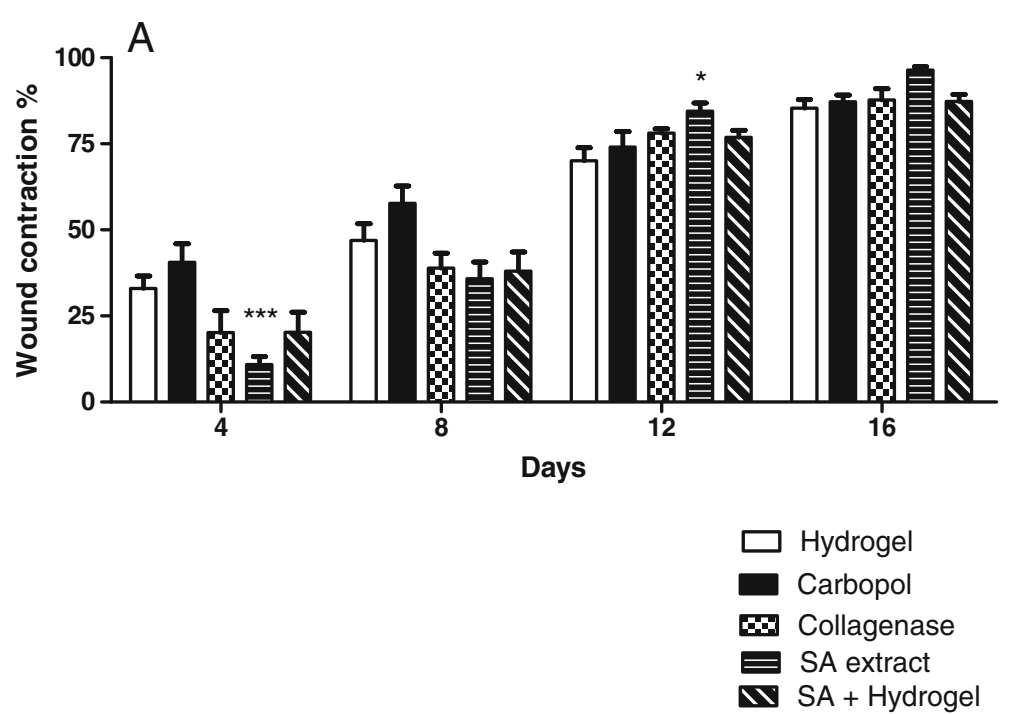

B

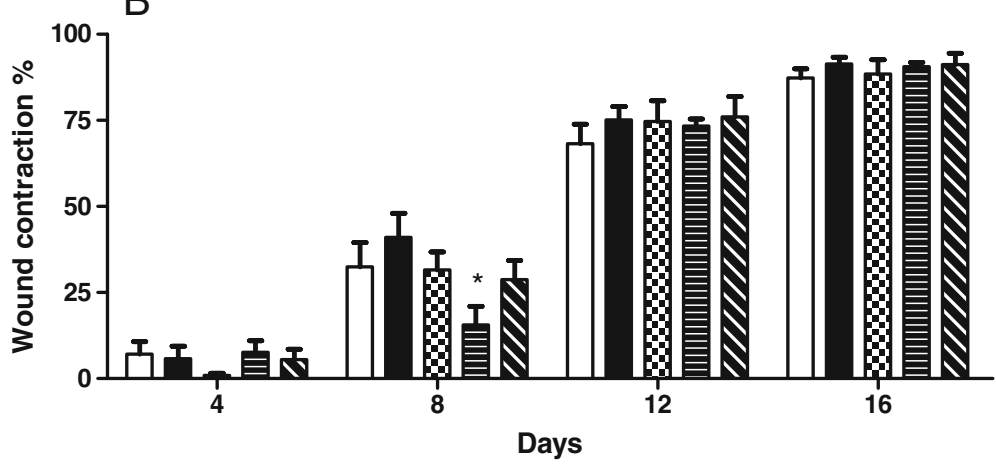

Fig. 3 Cutaneous wound contraction measurements in the non-diabetic animals (a) and in the diabetic animals (b) on days 4, 8, 12, and 16. Each column represents the mean \pm standard error of $5-7$ animals. ${ }^{*} p<0.05,{ }^{* * *} p<0.001$ represents the significance level in comparison to the Hydrogel group (Two-Way ANOVA, followed by Bonferroni's test)

$(2.37 \pm 0.26 ; 2.37 \pm 0.26 ; 2 \pm 0.32 ; 1.87 \pm 0.4)$ showed the best results over all of the days.

The experimental treatments in the diabetic animals showed better results in the Hydrogel group ( $2.8 \pm 0.31$; $2.2 \pm 0.16 ; 1.8 \pm 0.16 ; 2 \pm 0.0)$. The SAHE group ( $4.0 \pm$ $0.0 ; 4.0 \pm 0.0$ ) had the worst results until day 12 . However, on day 12 , the $\mathrm{H}+\mathrm{SAHE}$ group $(2.0 \pm 0.0, p<$ $0.001)$ performed higher than did the SAHE group $(3 \pm$ 0.45). On day 16, all of the groups revealed the same appearance.

\section{Histological analysis}

The dermis and the epidermis were analyzed (Table 2 and Fig. 6a). The scores of the crust in the controls during all of the experiments increased in the Collagenase and Chloramphenicol ${ }^{\circ}, \mathrm{H}+\mathrm{SAHE}$, and Carbopol groups; they remained high in Hydrogel group and decreased gradually in SAHE group.

In the dermis among the non-diabetic animals, a greater hemorrhage was observed in the $\mathrm{H}+\mathrm{SAHE}$ and
Carbopol-treated animals on day 8 of the treatments, followed by the Hydrogel group. The neovascularization of the animals that were treated with Hydrogel and $\mathrm{H}+$ SAHE presented higher values when compared to all of the other treatments. Collagenesis was evaluated on days 12 and 16. It was observed that among the non-diabetic animals, it was more expressive in the animals that were treated with $\mathrm{H}+\mathrm{SAHE}$, reaching the highest values on day 12 , and then decreasing on day 16 .

In the diabetic animals, the crust decreased during the treatments and it had a slight increase only in the SAHE group (Table 3 and Fig. 6b). Reepithelialization was more pronounced in the $\mathrm{H}+\mathrm{SAHE}$-treated animals in the non-diabetic animals and in the diabetic animals, as well as with the Collagenase with Chloramphenicol ${ }^{\circ}$ group, but only in the diabetic animals. The Hydrogel group on day 8 presented the greatest hemorrhage. The vessel formation increased throughout the treatments in all of the groups, except for the Collagenase with Chloramphenicol $^{\circledR}$ group and the SAHE group in the diabetic 

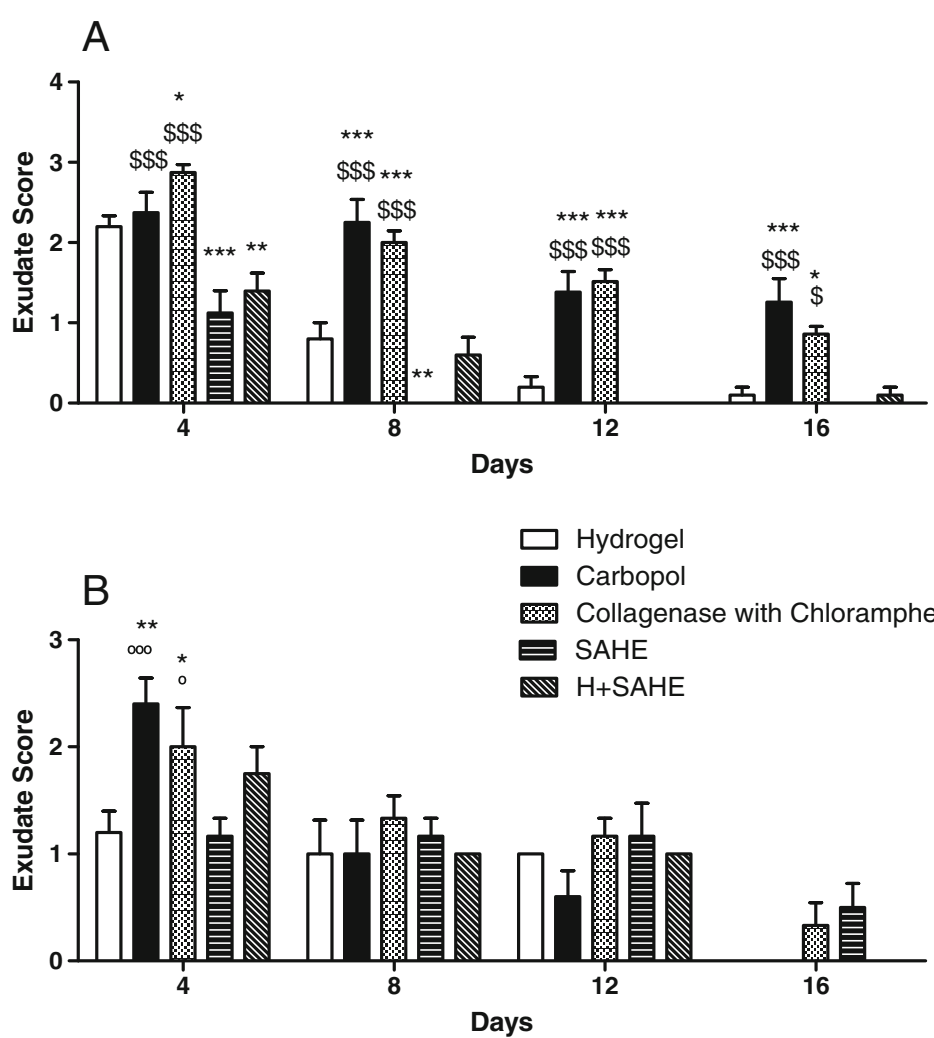

Fig. 4 The exudate scores of the cutaneous wounds in the non-diabetic animals (a), and in the diabetic animals (b), on days 4, 8, 12 , and 16. Each column represents the mean \pm standard error of $4-6$ animals. ${ }^{*} p<0.05,{ }^{* *} p<0.01,{ }^{* * *} p<0.001$, represents the level of significance when compared to the Hydrogel group; ${ }^{\$} p<0.05$ and ${ }^{\$ \$ \$} p<0.001$ when compared to the H+SAHE group; and ${ }^{\circ} p<0.05$ and ${ }^{\circ} p<0.001$ when compared with the SAHE group (Two-Way Analysis of Variance, followed by Bonferroni's test)

animals. Hydrogel presented the greatest neovascularization on day 8 , and this value remained the same during the treatments, whereas the $\mathrm{H}+\mathrm{SAHE}$ group showed greater neovascularization during the treatments, and on day 16, it overcame the Hydrogel group. The S. adstringens extract increased neovascularization in the diabetic animals. Collagenesis was also higher in the $\mathrm{H}+$ SAHEtreated animals, reaching these values on day 12 and on day 16.

\section{Discussion}

The phytochemical analysis of Stryphnodendron adstringens indicated the presence of tannins, phenolic compounds, and flavonoids. It is well known for the presence of these substances in the plants and in the other species of this genus, such as $S$. obovatum and $S$. polyphyllum [24]. Mello et al. isolated several flavonoids from $S$. adstringens barks, reinforcing the presence of these compounds [25]. It has already been proven that $S$. adstringens, at concentrations near to the levels that are found in commercial preparations, have exerted an in vitro genoprotective effect on the cells, by decreasing the levels of DNA oxidation, as well as by also indicating a decrease in the apoptotic events [26]. In this study, the extracts of $S$. adstringens displayed antioxidant activities against DPPH. The gels used did not demonstrate cytotoxicity, which indicated that these gels are safe to use in future evaluations.

In the present study, while using the HPLC analysis, the presence of gallic and caffeic acid was detected. Gallic acid had anti-inflammatory activities in both the in vivo and in vitro environments [27]. Besides, the presence of flavonoids, tannins, and phenolic acids also presented anti-inflammatory activities [28], In addition, they acted on cell migration and fibroblast proliferation [29]. This fact could explain the better healing of the wounds that were found in the $\mathrm{H}+\mathrm{SAHE}$-treated animals since the healing was faster and the appearance of the wounds was much better. Moreover, the $\mathrm{H}+\mathrm{SAHE}$-treated animals also induced a better mending in the scratch assay. This data has confirmed the greater capacity of fibroblast migration in the animals that were treated with $\mathrm{H}+$ SAHE; therefore, this had a greater effect on the recovery of the lesions.

The presence of $S$. adstringens in the treatments showed a significantly reduced presence of exudate. Both 

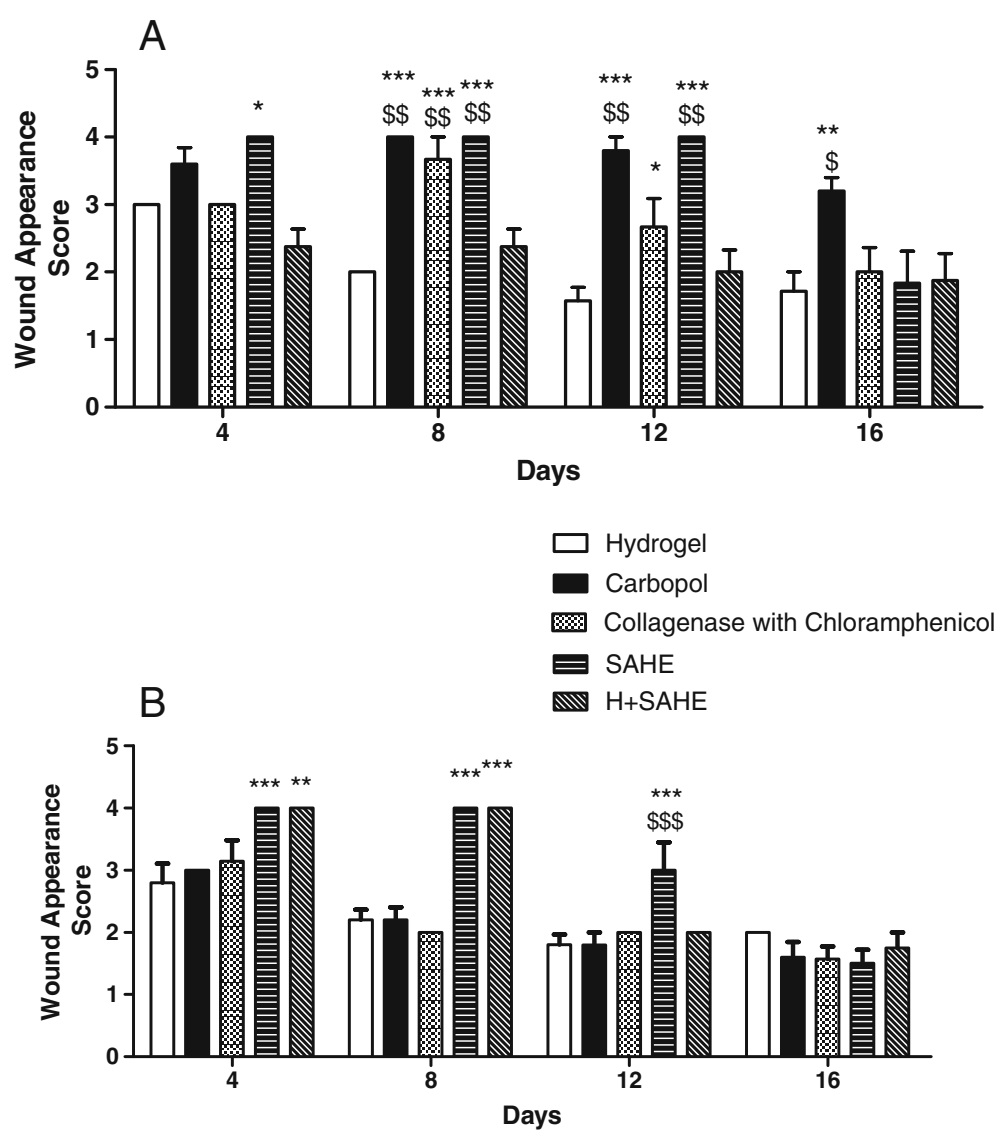

Fig. 5 The wound appearance scores of the cutaneous wounds in the non-diabetic animals (a), and in the diabetic animals (b)), on days 4, 8, 12, and 16. Each column represents the mean \pm standard error of 4-8 animals, ${ }^{*} p<0.05,{ }^{* *} p<0.01,{ }^{* * *} p<0.001$, represents the level of significance when compared to the Hydrogel group; and ${ }^{\$ \$} p<0.01$ and ${ }^{\$ \$} p<0.001$ represents the level of significance when compared to the $H+$ SAHE group (Two-Way Analysis of Variance, followed by Bonferroni's test)

the SAHE and the $\mathrm{H}+$ SAHE groups kept low levels of the exudate during the treatments. The healing and the repair of the wounds were accelerated by the use of Hydrogel, due to the presence of $0.9 \%$ sodium chloride in a moist environment that provided better humidity manipulation conditions, hence, reducing the number of changes [30]. The Hydrogel treatments in the control animals demonstrated at first, greater contractions of the wound, but they were overcome by the $\mathrm{H}+$ SAHE and SAHE groups at the end of the treatments, possibly by the $S$. adstringens healing activities. This fact has agreed with a study where the authors verified that the extracts

Table 2 Histological Parameters of the Controls Rats

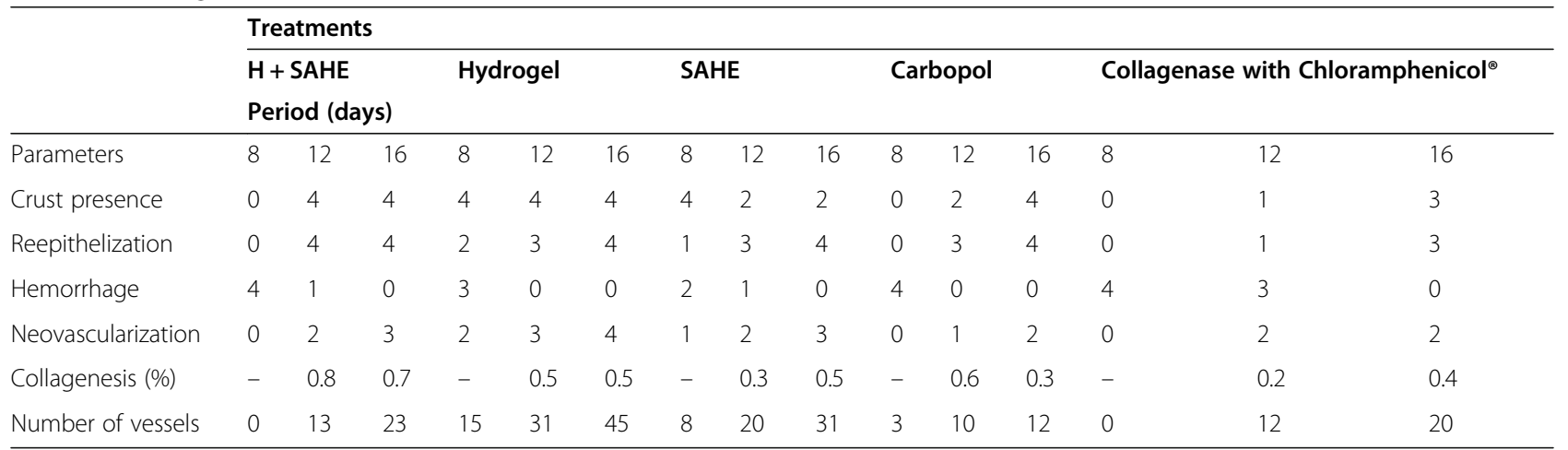

H\&E staining, score from 0 to 4: absent - until 15\% (0), very low - 20\% (1), low - 50\% (2), moderate - 80\% (3), and very high - 100\% (4). Masson's Trichrome Stain in \%. Number of Vessels per Lamina (all fields) 

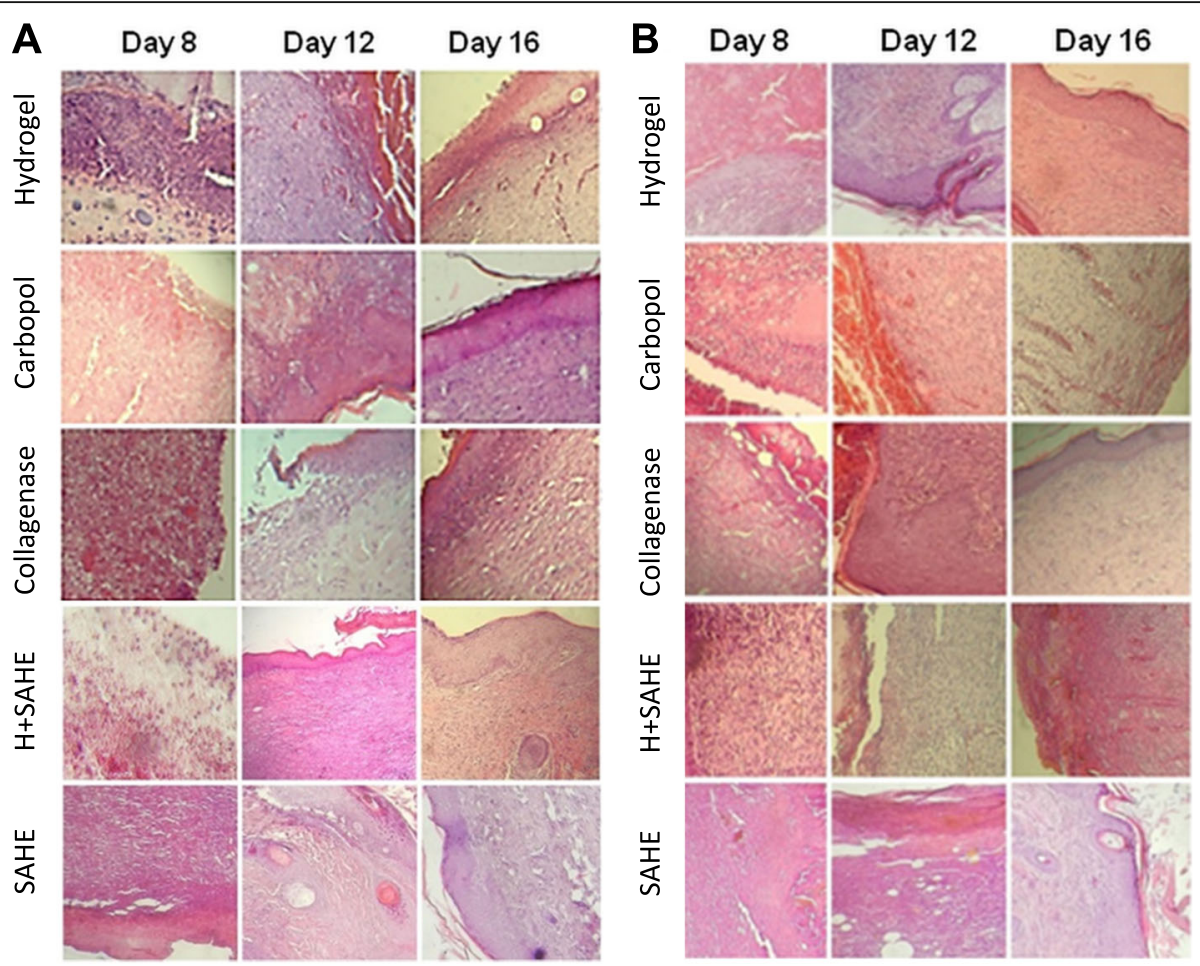

Fig. 6 Skin histology of the controls (a), and the diabetic animals (b), on days 8, 12, and 16, after the wonder lesion treatments with Hydrogel; Carbopol; Collagenase with Chloramphenicol ${ }^{\oplus}$; H + SAHE; SAHE. Staining H\&E, $10 \times 40$ magnification

of the stem barks of S. polyphyllum and S. obovatum presented cicatrizing effects when added to ointments and applied in cutaneous wounds in rats. An increase in the epidermal cell proliferation was also observed on treatment days 4 and 7 in the animals that were treated with S. polyphyllum [24].

The extract of $S$. adstringens was used to repair the wound tissues in the diabetic rats, stimulating the production of collagen fibers at the lesion site. This favored the formation of a more organized extracellular matrix and stimulated the filling of the lesion. The authors have linked these results to the presence of tannins and the high levels of gallic acid that were found in the extract [31, 32]. Rabelo et al. [33] described the healing of skin lesions in dogs when using a $10 \%$ S. adstringens ointment. On the first evaluation that was performed after the sixth day of the wound establishment, granulation tissue, and an epithelial onset with a reduction of the injured area was observed in all of the animals. Overall, in the present study, for both the non-diabetic animals and the diabetic animals, collagenesis was more expressive in the $\mathrm{H}+\mathrm{SAHE}$ treated animals.

Table 3 Histological Parameters of the Diabetics Rats

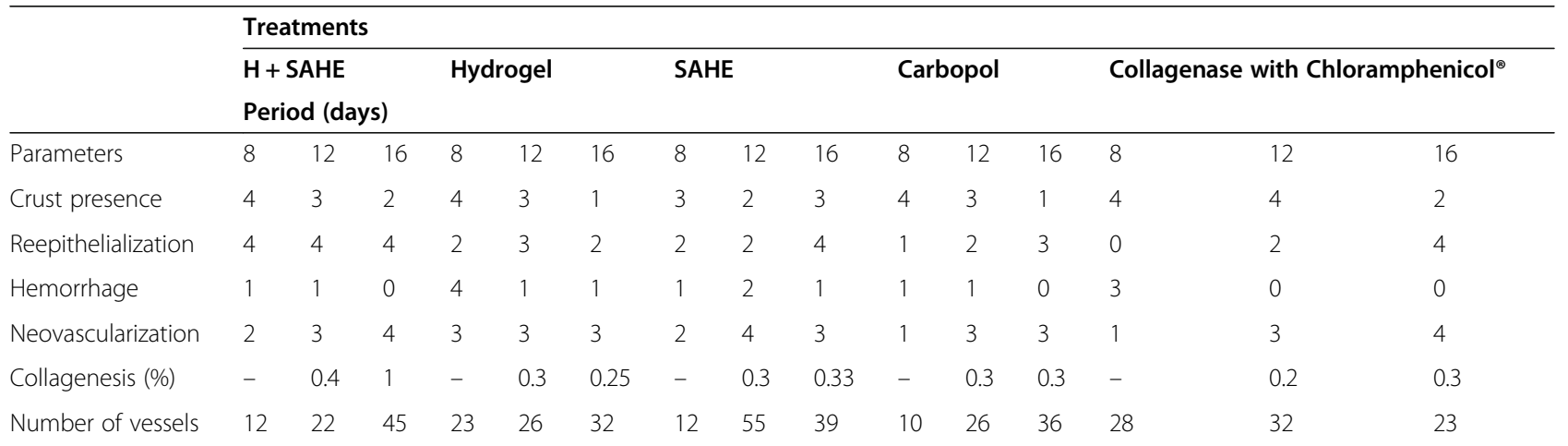

H\&E staining, score from 0 to 4: absent - until 15\% (0), very low - 20\% (1), low - 50\% (2), moderate - 80\% (3), and very high - 100\% (4). Masson's Trichrome Stain in \%. Number of Vessels per Lamina (all fields) 
The non-diabetic animals presented a greater contraction of the wounds and with a greater crust formation when in comparison to the diabetic animals. This was a fact justified by the many deleterious effects of the disease that decreased the inflammatory response, the granulocytic response, and slowed the epithelization process [34]. The aqueous solution of $S$. adstringens increased the percentages of the vessels formed, demonstrating the angiogenic capacity of S. adstringens [35], a fact that justified the presence of a greater number of vessels in the hyperglycemic animals that were treated with Hydrogel and $\mathrm{H}+\mathrm{SAHE}$.

Around the world, due to the high cost of allopathic medicines, the search for alternative therapies, especially for medicinal plants, has become increasingly necessary. As shown in this research, $\mathrm{H}+$ SAHE promoted greater reepithelialization in both the non-diabetic animals and in the diabetic rats. Further studies need to be performed, in order to verify the effects of the $S$. adstringens extracts, on successful wound healing of clinical diabetic patients.

\section{Conclusion}

S. adstringens has suggested a greater healing activity, mainly due to the synergism among the high concentration of tannins and other phenolic compounds. Therefore, the findings in this study have showed that $\mathrm{H}+$ SAHE showed healing effects in both the non-diabetic animals and in the diabetic rats, by promoting angiogenesis, collagenesis, reepithelialization, and the ability to promote cell proliferation and migration. This study has demonstrated that in the future, these associations constitute a safe and accessible therapeutic alternative for the treatment of this type of wounds in humans.

\begin{abstract}
Authors' contributions
Conceptualization: Patrícia de Souza Aguiar, Alessandra Hubner de Souza. Data Curation, Formal Analysis, Validation, and Visualization: Patrícia de Souza Aguiar, Flavia Tasmin Techera Antunes, Alessandra Hubner de Souza, Ivana Grivicich, Alexandre de Barros Falcão Ferraz, Dione Silva Corrêa. Investigation and Methodology: Suele Bierhals Vencato, Elenir Willand, Gabriela Jouglard Vasques Amado, Patrícia de Souza Aguiar, Áurea Pandolfo Correa, Ivana Grivicich, Dione Silva Corrêa, Alexandre de Barros Falcão Ferraz. Project Administration and Supervision: Alessandra Hubner de Souza. Resources and Funding Acquisition: Patrícia de Souza Aguiar, Alessandra Hubner de Souza. Writing - Original Draft and Article Writing \& Review \& Editing: Flavia Tasmin Techera Antunes, Áurea Pandolfo Correa, Patrícia Aguiar, Alexandre de Barros Falcão Ferraz, Alessandra Hubner de Souza. The authors read and approved
\end{abstract} the final manuscript.

\section{Funding}

This work was supported by ULBRA.

\section{Availability of data and materials}

The datasets used and/or analyzed during the current study are available from the corresponding author on reasonable request.

\section{Ethics approval and consent to participate}

Swiss male mice (35-40 g) were obtained from the vivarium of the Lutheran University of Brazil (ULBRA). Animal care and experimental procedures were strictly conducted in accordance with the ARRIVE Guidelines (Kilkenny et al 2011). All experiments were performed under the consent and surveillance of the Ethics Committee for Using Animals from ULBRA under Protocol $n^{\circ}$ 2013-20P.

\section{Consent for publication}

Not applicable.

\section{Competing interests}

The authors declare that they have no conflicts of interest related to this research.

\section{Author details}

${ }^{1}$ Postgraduate Program in Cellular and Molecular Biology Applied to Health, Lutheran University of Brazil, Av. Farroupilha, 8001, District São José, Canoas, Rio Grande do Sul 92425900, Brazil. ²Department of Pharmacy, Lutheran University of Brazil, Canoas, Rio Grande do Sul, Brazil.

Received: 28 November 2020 Accepted: 2 February 2021

Published online: 17 February 2021

\section{References}

1. Gantwerker EA, Hom DB. Skin: histology and physiology of wound healing. Facial Plast Surg Clin North Am. 2011;19:441-53.

2. Sinno H, Prakash S. Complements and the wound healing cascade: an updated review. Plastic Surg Internat. 2013;2013:1-7. http://dx.doi.org/10.11 55/2013/146764

3. Prakash A, Pandit PN, Sharman LK. Studies in wound healing in experimental diabetes. Int Surg. 1974;59:25-8

4. Fahey TJ, Sadaty A, Jones WG, Barber A, Smoller B, Shires GT. Diabetes impairs the late inflammatory response to wound healing. J Surg Res. 1991; 50:308-13.

5. Broughton $G$, Janis JE, Attinger CE. The basic science of wound healing. Plast Reconstr Surg. 2006;117:12S-34S

6. Okan D, Woo K, Ayello EA, Sibbald G. The role of moisture balance in wound healing. Adv Skin Wound Care. 2007;20(Suppl 1):39-53.

7. Martin JM, Zenilman JM, Lazarus GS. Molecular microbiology: new dimensions for cutaneous biology and wound healing. J Invest Dermatol. 2009:130:38-48.

8. Francesko A, Petkova P, Tzanov T. Hydrogel dressings for advanced wound management. Curr Med Chem. 2018;25(41):5782-97.

9. Sanches AC, Lopes GC, Nakamura CV, Dias Filho BP, Mello JC. Atividades antioxidantes e antifúngicas de extratos e taninos condensados de Stryphnodendron obovatum Benth. Braz J Pharm Sci. 2005:41:101-7.

10. Souza-Moreira TM, Queiroz-Fernandes GM, Pietro RCLR. Stryphnodendron species known as "Barbatimão": a comprehensive report. Molecules. 2018; 23(4):910

11. Ricardo LM, Dias BM, Mügge FLB, Leite W, Brandão MGL. Evidence of traditionality of Brazilian medicinal plants: the case studies of Stryphnodendron adstringens (Mart.) Coville (barbatimão) barks and Copaifera spp. (copaíba) oleoresin in wound healing. J Ethnopharmacol. 2018;219: 319-36.

12. Minatel DG, Pereira AM, Chiaratti TM, Pasqualin L, Oliveira JC, Couto LB, et al. Clinical study for the validation of the efficacy of ointment containing barbatimão (Stryphnodendron adstringens (Mart.) Coville) on the healing of decubitus ulcers. Rev Bras Med. 2010;67:250-6.

13. Falkenberg $M B$, Santos RI, Simões $C M O$. Introdução à Análise Fitoquímica. In: Simões CMO, Schenkel EP, Gosmann L, Mello JCP, Mentz LA, Petrovick PR, editors. Farmacognosia: da planta ao Medicamentos. Porto Alegre: UFRGS; 2003. p. 230-88.

14. Harborne JB. Phytochemical methods. Oxford: Clarendon Press; 1998. p. 295

15. Wagner H, Bladt S. Plant drug analysis - a thin layer chromatography atlas, vol. 384. Berlin: Springer; 1996.

16. Singleton $\mathrm{VL}$, Rossi JA Jr. Colorimetry of total phenolics with phosphomolybdic-phosphotungstic acid reagents. Am J Enol Vitic. 1965;16: 144-58.

17. Miliauskas G, Venskutonis PR, Van Beek TA. Screening of radical scavenging activity of some medicinal and aromatic plant extracts. Food Chem. 2004:85: $231-7$. 
18. Mensor LL, Menezes FS, Leitão GG, Reis AS, dos Santos TC, Coube CS, Leitão SG. Screening of Brazilian plant extracts for antioxidant activity by the use of DPPH free radical method. Phytother Res. 2001;15:127-30.

19. Scudiero DA, Shoemaker RH, Paull KD, Monks A, Tierney S, Thomas H, et al, Evaluation of a soluble tetrazolium/fFormazan assay for cell growth and drug sensitivity in culture using human and other tumor cell lines. Cancer Res. 1988:48:4827-33.

20. Sigalas E, Regan JD, Kramer PR, Witherspoon DE, Opperman LA. Survival of human periodontal ligament cells in media proposed for the transport of avulsed teeth. Dent Traumatol. 2004;20(Suppl 1):21-8.

21. Liang CC, Park AY, Guan JL. In vitro scratch assay: a convenient and inexpensive method for analysis of cell migration in vitro. Nat Protoc. 2007; 2(2):329-33.

22. Kilkenny C, Browne W, Cuthill IC, Emerson M, Altman DG. NC3Rs reporting guidelines working group. Animal research: reporting in vivo experiments: the ARRIVE guidelines. Br J Pharmacol. 2010;160(7):1577-9.

23. Wu KK, Huan Y. Streptozotocin-induced diabetic models in mice and rats. Curr Protoc Pharmacol. 2008;Chapter 5:Unit 5.47. https://doi.org/10.1002/04 71141755.ph0547s40.

24. Lopes GC, Sanches AC, Nakamura CV, Dias Filho BP, Hernandes L, de Mello JC. Influence of extracts of Stryphnodendron polyphyllum Mart. And Stryphnodendron obovatum Benth. On the cicatrisation of cutaneous wounds in rats. J Ethnopharmacol. 2005;99(2):265-72.

25. Mello JCP, Petereit F, Nahrdstedt A. A flavan-3-ols and prodelphinidins from Stryphnodendron adstringens. Phytochemistry. 1996;41:807-13.

26. Pellenz NL, Barbisan F, Azzolin VF, et al. Analysis of in vitro cyto- and genotoxicity of barbatimão extract on human keratinocytes and fibroblasts. Biomed Res Int. 2018;2018:1942451.

27. Tsang MS, Jiao D, Chan BC, et al. Anti-inflammatory activities of pentaherbs formula, berberine, gallic acid, and chlorogenic acid in atopic dermatitis-like skin inflammation. Molecules. 2016;21(4):519.

28. De La Rosa LA, Alvarez-Parrilla E, Shahidi F. Phenolic compounds and antioxidant activity of kernels and shells of Mexican pecan (Carya illinoinensis). J Agric Food Chem. 2011;59:152-62.

29. Ponnusamy Y, Chear NJY, Ramanathan S, Lai CS. Polyphenols rich fraction of Dicranopteris linearis promotes fibroblast cell migration and proliferation in vitro. J Ethnopharmacol. 2015;168:305-14.

30. Payne WG, Posnett J, Alvarez O, Brown-Etris M, Jameson G, Wolcott R, et al. Prospective randomized clinical trial to assess the cost-effectiveness of a modern foam dressing versus a traditional saline gauze dressing in the treatment of stage II pressure ulcers. Ostomy Wound Manage. 2009; 55(Suppl 2):50-5.

31. Pinto SC, Bueno FG, Panizzon GP, Morais G, Dos Santos PV, Baesso ML, et al. Stryphnodendron adstringens: clarifying wound healing in Streptozotocininduced diabetic rats. Planta Med. 2015;81(Suppl 12-13):1090-6.

32. Luiz RLF, Vila TVM, Mello JCP, Nakamura CV, Rozental S, Ishida K. Proanthocyanidins polymeric tannin from Stryphnodendron adstringens are active against Candida albicans biofilms. BMC Complement Altern Med. 2015;15:68.

33. Rabelo RE, Silva TDP, Sant'ana FJF, Oliveira SL, Leão HF, Kanashiro TCB, Silva OC et al. Uso do barbatimão na cicatrização de feridas cutâneas iatrogênicas em cães [Use of barbatimão in the healing of iatrogenic skin wounds in dogs]. In: congresso de pesquisa, ensino e extenção da UFG CONPEEX, 3., 2006, Goiânia. Anais eletrônicos do XIV Seminário de Iniciação Cientifica [CD-ROM], Goiânia: UFG, 2006

34. Huijberts MS, Schaper NC, Schalkwijk CG. Advanced glycation end products and diabetic foot disease. Diabetes Metab Res Rev. 2008;24(Suppl 1):S19-24.

35. Chaves DA, Lemes SR, Araujo LA, Sousa MAM, Freitas GB, Lino-junior RS, et al. Avaliação da atividade angiogênica da solução aquosa do barbatimão (Stryphnodendron adstringens). Rev Bras PI Med. 2016;18:524-30.

\section{Publisher's Note}

Springer Nature remains neutral with regard to jurisdictional claims in published maps and institutional affiliations.

\section{Submit your manuscript to a SpringerOpen ${ }^{\circ}$ journal and benefit from:}

- Convenient online submission

- Rigorous peer review

- Open access: articles freely available online

- High visibility within the field

- Retaining the copyright to your article

Submit your next manuscript at $\boldsymbol{\nabla}$ springeropen.com 